\title{
Good Governance, Komitmen Profesional dan Akuntabilitas Layanan Publik, Locus of Control Sebagai Intervening
}

\author{
Iro Jationo ${ }^{1}$, Widarto Rachbini ${ }^{2}$ \\ 1,2 Universitas Pancasila, Jl. Srengseng Sawah, Jagakarsa, Jakarta Selatan 12640
}

\section{N F O A R T I K E L}

\section{JEL Classification:}

H53

Keywords:

good governance,

professional commitment,

locus of control,

accountability.

\section{A $B$ S S T R A $\boldsymbol{C}$ T}

This research aims to empirically examine the relationship between good governance and professional commitment to accountability of public service procurement of goods/services through the government's locus of control as an intervening variable. The population in this research are all service personnel procurement of goods / services certified government spread across 42 SKPDs (working units) in Tangerang City Government which is responsible for the procurement of goods / services of the government, as many as 70 people. In this research, variables used consisted of the dependent variable accountability of public service procurement of goods/services of the government while the independent variable is good governance and professional commitment, and locus of control variable as an intervening variable. The results showed that the governance and professional commitments do not affect the accountability. locus of control significantly influence accountability. In this study, locus of control is not a variable pemediasi on accountability procurement of goods and services.

\section{A B S T R A K}

Penelitian ini bertujuan untuk menguji secara empiris hubungan antara tata kelola yang baik dan komitmen profesional terhadap akuntabilitas pengadaan pelayanan publik barang/jasa melalui locus of control pemerintahan sebagai variabel intervening. Populasi dalam penelitian ini adalah seluruh tenaga pelayanan pengadaan barang/jasa pemerintah bersertifikat yang tersebar di 42 SKPD (satuan kerja) di Pemerintah Kota Tangerang yang bertanggung jawab untuk pengadaan barang/jasa pemerintah, sebanyak 70 orang. Pada penelitian ini, variabel yang digunakan terdiri dari akuntabilitas pengadaan pelayanan publik barang/jasa pemerintah sebagai variabel dependen sedangkan variabel independen adalah tata kelola yang baik dan komitmen profesional, dan locus of control sebagai variabel intervening. Hasil penelitian menunjukkan bahwa tata kelola pemerintah dan komitmen profesional tidak berpengaruh terhadap akuntabilitas. Locus of control berpengaruh signifikan terhadap akuntabilitas. Pada penelitian ini, locus of control bukan merupakan variabel pemediasi pada akuntabilitas pengadaan barang dan jasa.

\section{Pendahuluan}

Tuntutan masyarakat terhadap akuntabilitas sektor publik untuk terwujudnya tata kelola pemerintahan yang baik (good governance) di Indonesia semakin meningkat. Menurut KNKG (Komite Nasional Kebijakan

*Email Korespondensi: 'iro_jationo@yahoo.com, 2wid4rto@gmail.com 
Governance, terdapat lima aspek utama yang mendukung terciptanya tata kelola kepemerintahan yang baik (good governance), yaitu transparansi, akuntabiltas, responsibilitas, independensi, kewajaran dan kesetaraan.

Akuntabilitas sektor publik berhubungan dengan praktik transparansi dan pemberian informasi kepada publik dalam rangka pemenuhan hak publik. Salah satu sektor publik yang diragukan akuntabilitas dalam pelaksanaannya adalah tata kelola pengadaan barang/jasa pemerintah atau yang lebih dikenal dengan lelang (procurement). Pengadaan barang/jasa pemerintah diartikan dengan kegiatan pengadaan barang/jasa pemerintah yang dibiayai dengan APBD/APBN, baik yang dilaksanakan secara swakelola, maupun oleh penyedia barang/jasa pemerintah atau dunia usaha. Permasalahan yang akan diteliti dirumuskan sebagai berikut:

1. Apakah good governance berpengaruh terhadap akuntabilitas layanan publik pengadaan barang/jasa pemerintah?

2. Apakah komitmen profesional berpengaruh terhadap akuntabilitas layanan publik pengadaan barang/jasa pemerintah?

3. Apakah locus of control berpengaruh terhadap akuntabilitas layanan publik pengadaan barang/jasa pemerintah?

4. Apakah locus of control mengintervening hubungan antara good governance dengan akuntabilitas layanan publik pengadaan barang/jasa pemerintah?

5. Apakah locus of control mengintervening hubungan antara good governance dengan akuntabilitas layanan publik pengadaan barang/jasa pemerintah?

\section{Kajian Teori}

Kajian teori yang mejadi acuan dalam penelitian ini adalah sebagaimana tabel 1.

\section{Metode}

Data yang digunakan dalam penelitian ini adalah data primer yang diperoleh melalui survey dengan menggunakan daftar pertanyaan (kuesioner) yang telah terstruktur dengan tujuan untukmengumpulkaninformasidenganresponden aparatLayanan Pengadaan barang/jasapemerintah di Pemerintah Kota Tangerang. Populasi dalam penelitian ini adalah seluruh aparat Layanan Pengadaan barang/jasa pemerintah bersertifikat yang tersebar di 42 SKPD di Pemerintah Kota Tangerang yang bertanggung jawab terhadap proses pengadaan barang/jasa pemerintah, yaitu sebanyak 70 orang. Karena jumlah populasi kurang dari 100 responden, maka metode pemilihan sampel yang digunakan adalah metode sensus, yaitu penyebaran kuesioner dilakukan pada semua populasi. Jumlah kuesioner yang dibagikan kepada responden adalah sebanyak jumlah populasi yaitu 70 kuesioner.

Penelitian ini dilakukan di Unit Layanan Pengadaan barang/jasa pemerintah Kota Tangerang pada tahun 2014. Pemilihan Pemerintah Kota Tangerang sebagai lokasi penelitian didasarkan pada pertimbangan bahwa masih diperlukannya upaya peningkatan Akuntabilitas Layanan Pengadaan barang/jasa pemerintah di Kota Tangerang.

Dalam penelitian ini, variabel yang digunakan terdiri dari variabel dependen Akuntabilitas layanan publik pengadaan barang/jasa pemerintah sedangkan variabel independennya adalah good governnace dan komitmen profesional, serta variabel locus of control sebagai variabel intervening. Kuesioner sebagai Instrumen penelitian merupakan media dalam pengumpulan data. Kuesioner dikatakan reliabel jika jawaban responden konsisten saat diajukan pertanyaan yang sama pada waktu yang berbeda. Untuk menguji kualitas data yang diperoleh dari penerapan instrumen, maka diperlukan uji validitas, dan uji reliabilitas dengan penjelasan sebagai berikut:

Pengujian data menggunakan beberapa uji statistik yaitu, Uji validitas adalah untuk mengetahui sah tidaknya instrumen kuisioner yang digunakan dalam pengumpulan data. Uji validitas ini dilakukan untuk mengetahui apakah item-item yang tersaji dalam kuesioner benarbenar mampu mengungkapkan dengan pasti apa yang akan diteliti (Ghozali, 2006). Sebagaimana dikutip oleh Sugiyono (2008), 
Tabel 1.

Penelitian Terdahulu

\begin{tabular}{|c|c|c|c|c|}
\hline No. & Judul & Kesimpulan & Peneliti & Perbedaan \\
\hline 1 & $\begin{array}{l}\text { e-Procurement dalam } \\
\text { Pengadaan barang/ } \\
\text { jasa pemeirntah } \\
\text { untuk mewujudkan } \\
\text { Akuntabilitas di Kota } \\
\text { Yogyakarta }\end{array}$ & $\begin{array}{l}\text { Pengadaan barang/jasa } \\
\text { pemerintah secara on- } \\
\text { line di Kota Yogyakarta } \\
\text { tahun } 2009 \text { fisibel tapi } \\
\text { tidak akuntabel }\end{array}$ & $\begin{array}{l}\text { Kodar Udoyono } \\
\text { (2012) }\end{array}$ & $\begin{array}{l}\text { Memperluas variabel indepen- } \\
\text { den e-procurement menjadi good } \\
\text { governance dan menambah } \\
\text { variabel independen komitmen } \\
\text { profesional dan variabel locus of } \\
\text { control sebagai intervening }\end{array}$ \\
\hline 2. & $\begin{array}{l}\text { Pengaruh Penerapan } \\
\text { pengadaan barang/ } \\
\text { jasa pemerintah } \\
\text { secara on line } \\
\text { (e-Procurement) } \\
\text { terhadapPeningkatan } \\
\text { Kualitas Kinerja dan } \\
\text { Pelayanan Publik }\end{array}$ & $\begin{array}{l}\text { terdapatpengaruhpositif } \\
\text { dan signifikan antara } \\
\text { penerapan pengadaan } \\
\text { barang/jasa pemerintah } \\
\text { secara on line terhadap } \\
\text { variabel kualitas kinerja } \\
\text { dan serta berpengaruh } \\
\text { positif namun tidak } \\
\text { signifikan dengan } \\
\text { kualitas pelayanan } \\
\text { publik pada Dinas } \\
\text { Pendidikan Propinsi } \\
\text { Kepulauan Riau. }\end{array}$ & Adimaja (2010) & $\begin{array}{l}\text { Memperluas variabelindependen } \\
\text { e-procurement menjadi good } \\
\text { governance dan menambah } \\
\text { variabel independen komitmen } \\
\text { profesional dan variabel locus of } \\
\text { control sebagai intervening }\end{array}$ \\
\hline 3. & $\begin{array}{l}\text { E-procurement: } \\
\text { How does it } \\
\text { enhance strategic } \\
\text { performance? }\end{array}$ & $\begin{array}{l}\text { keselarasan antara } \\
\text { strategi bisnis, strategi } \\
\text { pengadaan barang/ } \\
\text { jasa secara on line } \\
\text { (e-procurement), alat } \\
\text { pengadaan barang/ } \\
\text { jasa secara on line, } \\
\text { strategi kemampuan IT } \\
\text { dan tipologi strategis } \\
\text { memiliki pengaruh } \\
\text { positif terhadap kinerja } \\
\text { strategis perusahaan. }\end{array}$ & $\begin{array}{l}\text { Paul Phillips } \\
\text { and Wojciech } \\
\text { Piotrowicz } \\
\text { (2006) }\end{array}$ & $\begin{array}{l}\text { Memperluasvariabelindependen } \\
\text { e-procurement menjadi good } \\
\text { governance dan menambah } \\
\text { variabel independen komitmen } \\
\text { profesional dan variabel locus } \\
\text { of control sebagai intervenig }\end{array}$ \\
\hline
\end{tabular}

Masrun menjelaskan bahwa dalam memberikan interpretasi terhadap koefisien korelasi, item yang mempunyai korelasi positif dengan skor total menunjukkan bahwa item tersebut mempunyai validitas yang tinggi. Uji validitas dilakukan dengan uji korelasi Pearson Moment antara masing-masing skor indikator dengan total skor konstruk. Suatu butir pertanyaan dikatakan valid jika nilai korelasi item butir dengan skor total signifikan pada tingkat signifi- kansi 0,01 dan 0,02.

Uji Reliabilitas dimana suatu kuesioner dikatakan handal atau reliabel jika jawaban seseorang terhadap pertanyaan adalah konsisten atau stabil dari waktu ke waktu. Uji reliabilitas dilakukan dengan metode internal consistency. Kriteria yang digunakan dalam uji ini adalah One Shot, artinya satu kali pengukuran saja dan kemudian hasilnya dibandingkan dengan pertanyaan lainnya atau dengan kata lain 
mengukur korelasi antar jawaban pertanyaan. Statistical Product and Service Solution (SPSS) memberikan fasilitas untuk mengukur reliabilitas dengan uji statistik Cronbach Alpha ( $\alpha$ ). Jika nilai koefisien alpha lebih besar dari 0,60 maka disimpulkan bahwa intrumen penelitian tersebut handal atau reliabel (Nunnaly dalam Ghozali, 2006).

Sebelum data dianalisis lebih lanjut menggunakan analisis regresi berganda, terlebih dahulu dilakukan uji asumsi klasik yang terdiri dari: uji normalitas, uji multikolinieritas, dan uji heterokedastisitas. Uji normalitas bertujuan untuk menguji apakah dalam model regresi, variabel dependen dan independen keduanya mempunyai distribusinormalatautidak(Ghozali, 2006). Model regresi yang baik adalah memiliki distribusi data normal atau mendekati normal. Uji normalitas data tersebut dapat dilakukan melalui 3 cara yaitu menggunakan Uji Kolmogorof-Smirnov (Uji K-S), grafik histogram dan kurva penyebaran P-Plot. Untuk Uji K-S yakni jika nilai hasil Uji K-S > dibandingkan taraf signifikansi 0,05 maka sebaran data tidak menyimpang dari kurva normalnya itu uji normalitas. Sedangkan melalui pola penyebaran Plot dan grafik histogram, yakni jika pola penyebaran memiliki garis normal maka dapat dikatakan data berdistribusi normal.

Uji Multikolinieritas, Uji ini dimaksudkan untuk mendeteksi gejala korelasi antara variabel independen yang satu dengan variabel independen yang lain. Pada model regresi yang baik seharusnya tidak terdapat korelasi di antara variabel independen. Uji Multikolinieritas dapat dilakukan dengan 2 cara yaitu dengan melihat VIF (Variance Inflation Factors) dan nilai tolerance. Jika VIF $>10$ dan nilai tolerance $<0,10$ maka terjadi gejala Multikolinieritas (Ghozali, 2006). Uji multikolinieritas bertujuan untuk menguji apakah dalam suatu model regresi ditemukan adanya korelasi antar variabel independen penelitian. Model regresi yang baik seharusnya tidak terjadi korelasi diantara variabel independen. Ada tidaknya korelasi antar variabel tersebut dapat dideteksi dengan melihat nilai tolerance dan Variance Inflation Factor (VIF). Apabila nilai tolerance $>0,1$ dan VIF $<$
10, maka dinyatakan tidak ada korelasi sempurna antar variabel independen dan sebaliknya (Ghozali, 2006). Istilah kolinearitas ganda (multicollinearity) diciptakan oleh Ragner Frish di dalam bukunya: Statistical confluence analysis by means of Complete Regression System. Aslinya, istilah multikolinearitas itu berarti adanya hubungan linear yang sempurna atau eksak (perfect or exact) di antara variabel-variabel bebas dalam model regresi. Istilah kolinearitas ganda (multicollinearity) menunjukkan adanya lebih dari satu hubungan linear yang sempurna.

Uji heteroskedastisitas bertujuan untuk menguji apakah dalam model regresi terjadi ketidaksamaan variance dari residual satu pengamataan ke pengamatan yang lain tetap, atau disebut homoskedastisitas. Model regresi yang baik adalah yang homoskedastisitas, tidak heteroskedastisitas. Heteroskedastisitas ditandai dengan adanya pola tertentu pada grafik scatterplot. Jika titik-titik yang ada membentuk suatu pola tertentu yang teratur (bergelombang), maka terjadi heteroskedastisitas. Jika tidak ada pola yang jelas, titik-titik menyebar di atas dan di bawah angka nol pada sumbu Y, maka tidak terjadi heteroskedastisitas. Selain itu, heteroskedastisitas dapat diketahui melalui uji Glesjer. Jika probabilitas signifikansi masingmasing variabel independen $>0,05$, maka dapat disimpulkan tidak terjadi heteroskedastisitas dalam model regresi (Ghozali, 2006).

Pengujian hipotesis dilakukan dengan menggunakan model analisis regresi berganda bertujuan untuk memprediksi berapa besar kekuatan pengaruh variabel independen terhadap variabel dependen dan berapa besar kekuatan pengaruh variabel mediasi mempengaruhi hubungan antara variabel independen dan variabel dependen. Persamaannya adalah :

\section{Persamaan 1: $Y_{1}=\beta_{1.1} X_{1}+\beta_{1.2} X_{2}+C_{1}$}

Dimana :

$\mathrm{Y}_{1}=$ Locus of control

$\mathrm{X}_{1}=$ Good governance

$\mathrm{X}_{2}=$ Komitmen Profesional

$\beta=$ Koefisien Jalur

$\epsilon_{1}=$ Nilai Residu 
Persamaan 2: $\mathbf{Y}_{2}=\boldsymbol{\beta}_{2.1} \mathbf{X}_{1}+\boldsymbol{\beta}_{2.2} \mathbf{X}_{2}+\boldsymbol{\beta}_{2.3} \mathbf{X}_{3}+\mathbf{C}_{2}$ Dimana :

$\mathrm{Y}_{2}=$ Akuntabilitas Layanan Publik Pengadaan barang/jasa pemerintah

$\mathrm{X}_{1}=$ Good governance

$\mathrm{X}_{2}=$ Komitmen Profesional

$\mathrm{X}_{3}=$ Locus of control

$\beta=$ Koefisien Jalur

$\epsilon_{1}=$ Nilai Residu

Sementara itu, langkah-langkah untuk menguji pengaruh variabel independen, dilakukan dengan uji simultan dan uji parsial. Uji F digunakan untuk mengetahui ada tidaknya pengaruh simultan variabel-variabel independen terhadap variabel dependen. Kriteria pengujian yang digunakan adalah jika probability value ( $p$ value $)<0,05$, maka Ha diterima dan jika $p$ value $>0,05$, maka Ha ditolak. Uji F dapat pula dilakukan dengan membandingkan nilai Fhitung dan Ftabel. Jika Fhitung > F tabel (n-k-1), maka Ha diterima. Artinya, secara statistik data yang ada dapat membuktikan bahwa semua variabel independen $\left(\mathrm{X}_{1}, \mathrm{X}_{2}, \ldots\right)$ berpengaruh terhadap variabel dependen (Y). Jika Fhitung $<\mathrm{F}$ tabel (n-k-1), maka Ha ditolak. Artinya, secara statistik data yang ada dapat membuktikan bahwa semua variabel independen $\left(\mathrm{X}_{1}, \mathrm{X}_{2}, \ldots\right)$ tidak berpengaruh terhadap variabel dependen (Y). Selanjutnya Uji Parsial (Uji t), Uji t digunakan untuk mengetahui pengaruh masing-masing variabel independen terhadap variabel dependen. Kriteria pengujian yang digunakan adalah jika $p$ value $<0,05$, maka Ha diterima dan jika $p$ value $>$ 0,05, maka Ha ditolak. Uji t dapat pula dilakukan dengan membandingkan nilai thitung dan tabel. Jika thitung $>\mathrm{t}$ tabel (n-k-1), maka Ha diterima. Artinya, secara statistik data yang ada dapat membuktikan bahwa semua variabel independen $\left(\mathrm{X}_{1}, \mathrm{X}_{2}, \ldots\right)$ secara parsial berpengaruh terhadap variabel dependen (Y). Jika thitung $<\mathrm{t}$ tabel (n-k-1), maka Ha ditolak. Artinya, secara statistik data yang ada dapat membuktikan bahwa semua variabel independen $\left(\mathrm{X}_{1}, \mathrm{X}_{2}, \ldots\right)$ secara parsial tidak berpengaruh terhadap variabel dependen (Y).

\section{Hasil Penelitian Dan Pembahasan}

Uji validitas konstruk dilakukan untuk mengukur sah atau valid tidaknya suatu kuesioner. Suatu kuesioner dikatakan valid jika pernyataan kuesioner mampu untuk mengungkapkan sesuatu yang akan diukur oleh kuesioner tersebut. Uji signikansi dilakukan dengan membandingkan $\mathrm{r}$ hitung dengan $r$ tabel atau membandingkan nilai $\mathrm{p}$ atau sig dengan level of significance (biasanya $=0.05$ ). Jika $r$ hitung lebih besar dari $r$ tabel atau nilai $\mathrm{p}$ atau sig $<0.05$, maka pernyataan tersebut valid. Jumlah data pada uji validitas ini adalah 66, sehingga berdasarkan tabel $r$ dengan nilai sig $=0.05$, maka nilai $r$ tabel adalah 0.239 . Indikator item pernyataan yang memiliki nilai $\mathrm{r}$ hitung (Corrected Item-Total Correlation) > $r$ tabel dinyatakan valid dan dapat digunakan sebagai alat ukur variabel sedangkan Indikator item pernyataan yang memiliki nilai $r$ hitung (Corrected Item-Total Correlation) < $\mathrm{r}$ tabel dinyatakan tidak valid dan tidat dapat digunakan sebagai alat ukur variable (dieliminasi). Secara ringkas hasil uji validitas variabel dapat dilihat pada tabel 2.

Untuk pengujian reliabilitas dalam penelitian ini menggunakan uji One Shot, artinya satu kali pengukuran saja dan kemudian hasilnya dibandingkan dengan pernyataan lainnya atau dengan kata lain mengukur korelasi antar jawaban pernyataan. Hasil perhitungan uji reliabilitas menunjukkan bahwa nilai Cronbach Alpha $(\alpha)$ untuk masing-masing variabel adalah lebih besar dari 0,60, dengan demikian dapat disimpulkan bahwa item-item instrumen untuk masingmasing variabel adalah reliabel (Nunnally dalam Ghozali, 2006).

Berdasarkan hasil uji multikolinieritas diperoleh nilai tolerance variabel independen good governance dan komitmen profesional lebih besar dari 0,10 yang berarti tidak ada korelasi antar variabel indpenden yang nilainya lebih dari 95\%. Sementara, hasil nilai Variance Inflantion Factor (VIF) juga menunjukkan hal yang sama. Semua variabel independen memiliki nilai VIF lebih kecil dari 10. Dengan demikian dapat disimpulkan dalam model regresi tidak 
Tabel 2.

Hasil Uji Validitas Instrumen

\begin{tabular}{|c|c|c|c|c|c|c|}
\hline No & Item & $\begin{array}{c}\text { Nilai r hitung } \\
\text { (Corrected Item-Total } \\
\text { Correlation) }\end{array}$ & $\begin{array}{c}\text { Nilai r } \\
\text { tabel }\end{array}$ & Keputusan & Hasil & Keterangan \\
\hline 1. & GG1 & 0,159 & 0,239 & $\mathrm{r}$ hit $<\mathrm{r}$ tabel & Tidak Valid & Eliminasi \\
\hline 2. & GG2 & 0,350 & 0,239 & $\mathrm{r}$ hit $>\mathrm{r}$ tabel & Valid & \\
\hline 3. & GG3 & 0,194 & 0,239 & $\mathrm{r}$ hit $<\mathrm{r}$ tabel & Tidak Valid & Eliminasi \\
\hline 4. & GG4 & 0,295 & 0,239 & $\mathrm{r}$ hit $>\mathrm{r}$ tabel & Valid & \\
\hline 5. & GG5 & 0,069 & 0,239 & $\mathrm{r}$ hit $<\mathrm{r}$ tabel & Tidak Valid & Eliminasi \\
\hline 6. & GG6 & 0,430 & 0,239 & $\mathrm{r}$ hit $>\mathrm{r}$ tabel & Valid & \\
\hline 7. & KP1 & 0,416 & 0,239 & $\mathrm{r}$ hit $>\mathrm{r}$ tabel & Valid & \\
\hline 8. & KP2 & 0,251 & 0,239 & $\mathrm{r}$ hit $>\mathrm{r}$ tabel & Valid & \\
\hline 9. & KP3 & 0,419 & 0,239 & $\mathrm{r}$ hit $>\mathrm{r}$ tabel & Valid & \\
\hline 10. & KP4 & 0,396 & 0,239 & $r$ hit $>r$ tabel & Valid & \\
\hline 11. & KP5 & 0,331 & 0,239 & $r$ hit $>r$ tabel & Valid & \\
\hline 12. & KP6 & 0,166 & 0,239 & $\mathrm{r}$ hit $<\mathrm{r}$ tabel & Tidak Valid & Eliminasi \\
\hline 13. & KP7 & 0,033 & 0,239 & $\mathrm{r}$ hit $<\mathrm{r}$ tabel & Tidak Valid & Eliminasi \\
\hline 14. & LC1 & 0,346 & 0,239 & $\mathrm{r}$ hit $>\mathrm{r}$ tabel & Valid & \\
\hline 15. & LC2 & 0,157 & 0,239 & $\mathrm{r}$ hit $<\mathrm{r}$ tabel & Tidak Valid & Eliminasi \\
\hline 16. & LC3 & 0,285 & 0,239 & $\mathrm{r}$ hit $>\mathrm{r}$ tabel & Valid & \\
\hline 17. & LC4 & 0,574 & 0,239 & $\mathrm{r}$ hit $>\mathrm{r}$ tabel & Valid & \\
\hline 18. & LC5 & 0,415 & 0,239 & $\mathrm{r}$ hit $>\mathrm{r}$ tabel & Valid & \\
\hline 19. & LC6 & 0,316 & 0,239 & $\mathrm{r}$ hit $>\mathrm{r}$ tabel & Valid & \\
\hline 20. & AK1 & 0,410 & 0,239 & $\mathrm{r}$ hit $>\mathrm{r}$ tabel & Valid & \\
\hline 21. & AK2 & 0,300 & 0,239 & $\mathrm{r}$ hit $>\mathrm{r}$ tabel & Valid & \\
\hline 22. & AK3 & 0,329 & 0,239 & $r$ hit $>r$ tabel & Valid & \\
\hline 23. & AK4 & 0,508 & 0,239 & $\mathrm{r}$ hit $>\mathrm{r}$ tabel & Valid & \\
\hline 24. & AK5 & 0,318 & 0,239 & $\mathrm{r}$ hit $>\mathrm{r}$ tabel & Valid & \\
\hline 25. & AK6 & 0,251 & 0,239 & $\mathrm{r}$ hit $>\mathrm{r}$ tabel & Valid & \\
\hline
\end{tabular}

terjadi multikolinieritas antar variabel independen tersebut. Sedangkan hasil uji normalitas didapatkan nilai KS sebesar 0,370. Nilai ini tidak signifikan pada 0,05 (karena nilai $P=0,999$, lebih besar dari 0,05). Hal tersebut memberikan gambaran bahwa sebaran data tidak menunjukkan penyimpangan dari kurva normalnya, yang berarti bahwa sebaran data telah memenuhi asumsi normalitas. Untuk lebih memperjelas tentang sebaran data dalam penelitian ini maka akan disajikan dalam grafik histogram dan grafik normal P-plot. Dimana dasar pengambilan keputusan menurut Ghozali (2006) yaitu : Jika sumbu menyebar sekitar garis diagonal atau grafik histogramnya menunjukkan pola distribusi normal, maka model regresi memenuhi asumsi normalitas. Dan jika data menyebar jauh dari garis diagonal atau tidak mengikuti arah garis diagonal atau grafik histogram tidak menunjukkan pola distribusi normal, maka model regresi tidak memenuhi asumsi normalitas.

Dengan melihat tampilan grafik histogram maupun grafik normal P-Plot diatas dapat disimpulkan bahwa grafik histogram memberikan pola distribusi yang mendekati normal. Sedangkan pada grafik normal P-Plot terlihat titik-titik menyebar disekitar garis diagonal, serta arah penyebarannya mengikuti arah garis diagonal. Kedua grafik tersebut menunjukkan bahwa model regresi layak dipakai karena memenuhi asumsi normalitas. 


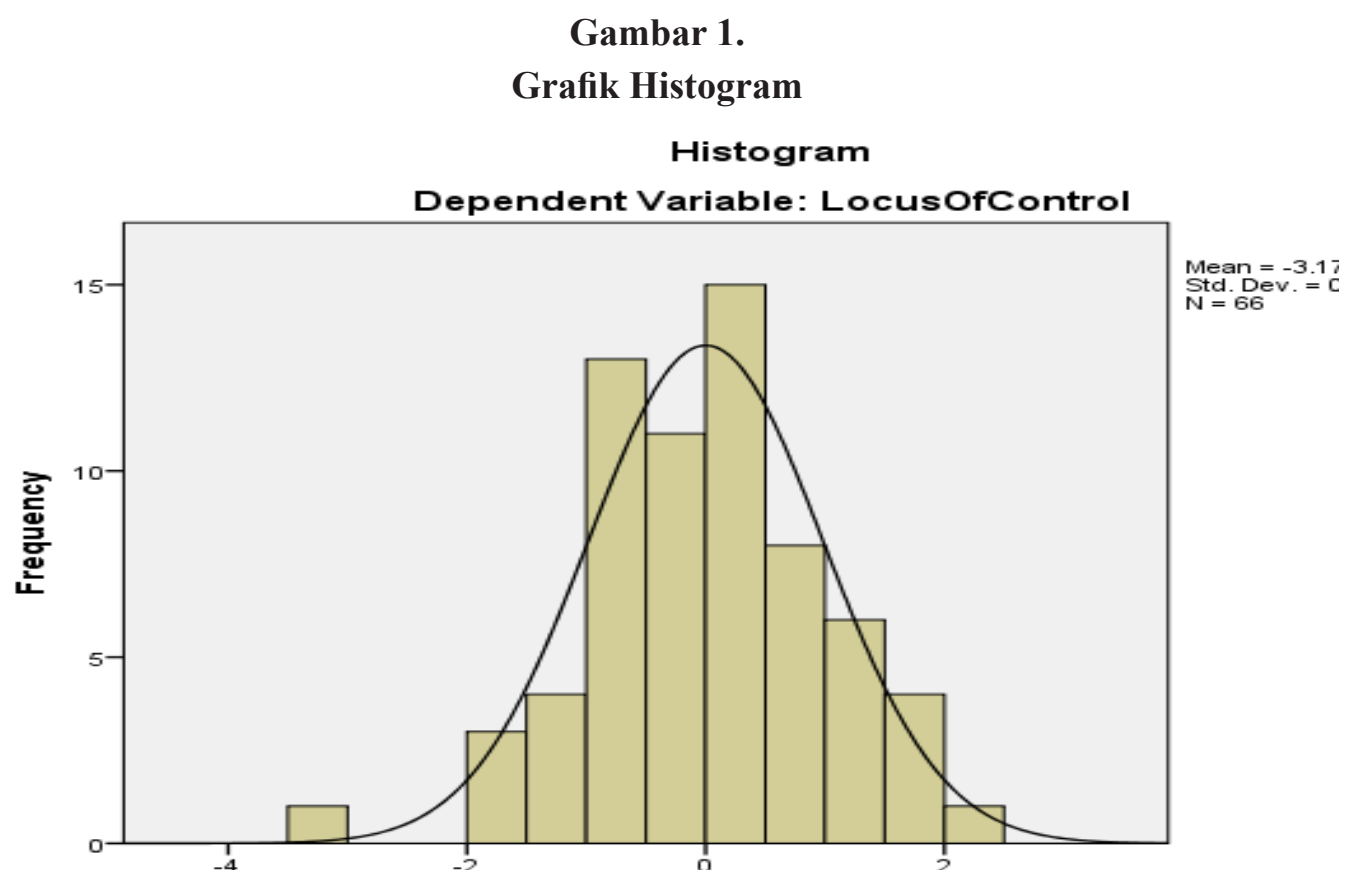

Gambar 2.

Grafik Normal

Normal P-P Plot of Regression Standardized Residual

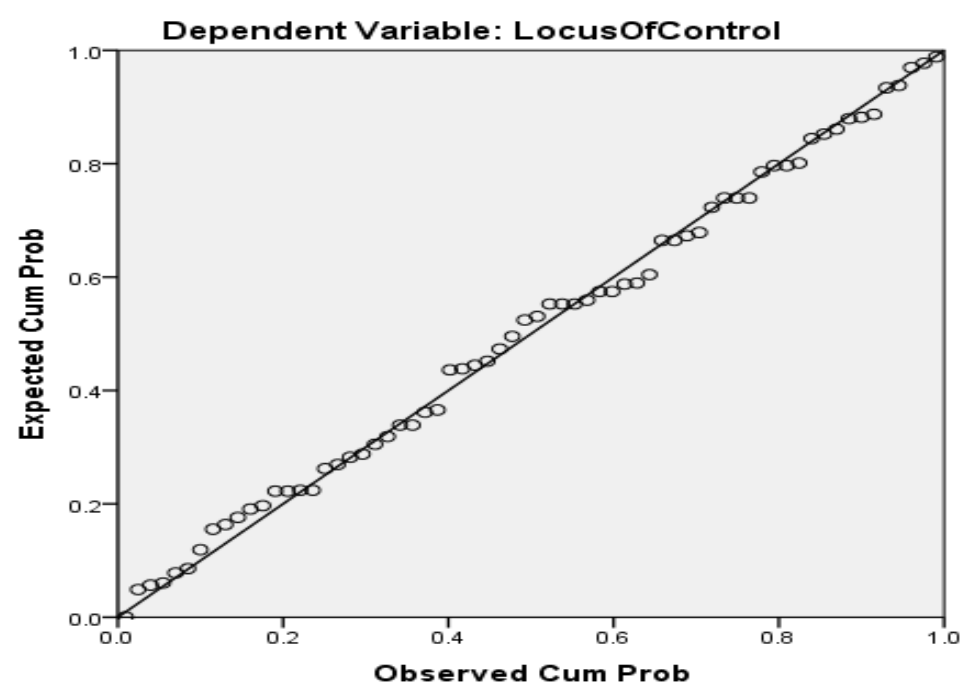

Untuk hasil dari masing-masing persamaan yaitu sebgai berikut :

1. Persamaan $1: Y_{1}=\beta_{1.1} X_{1}+\beta_{1.2} X_{2}+\epsilon_{1}$

Secara simultan good governance dan komitmen profesional berpengaruh signifikan terhadap locus of control. Besaran pengaruh simultan adalah 0,396 atau 39,60\% merupakan kontribusi dari variabel good governance dan komitmen profesional terhadap locus of control. Sedangkan sisanya $60,40 \%$ dipengaruhi faktor lain di luar model. Model simultan terjadi signifikan, dengan memperhatikan probablitas $\mathrm{F}$ sebesar 22,297 pada sig 0,000<0,05.

Setelah model simultan terbukti signifikan, maka dilakukan penelusuran jalur pengaruh parsial. Dari tiga variabel yang ditempatkan sebagai prediktor, good governance memiliki t-hit $>$ t-tab dan pvalue $<0,05$, sehingga dapat dikatakan bahwa good governance secara parsial berpengaruh signifikan terhadap locus of control. Besaran pengaruh parsial dan langsung 
good governance terhadap locus of control adalah sebesar 0,544 atau $54,40 \%$. Dengan demikian, tinggi rendahnya locus of control dipengaruhi oleh good governance sebesar $54,40 \%$, sedangkan sisanya $45,60 \%$ dijelaskan faktor lain di luar model. Komitmen profesional memiliki t-hit $>$ t-tab dan pvalue $<0,05$, sehingga dapat dikatakan bahwa komitmen profesional secara parsial berpengaruh signifikan terhadap locus of control. Besaran pengaruh parsial dan langsung komitmen profesional terhadap locus of control adalah sebesar 0,216 atau dibulatkan menjadi $21,60 \%$. Artinya, tinggi rendahnya locus of control dipengaruhi oleh komitmen profesional sebesar $78,40 \%$, sedangkan sisanya $65 \%$ dijelaskan faktor lain di luar model. Hal ini tentunya menjelaskan bahwa secara simultan dan parsial good governance dan komitmen profesional dapat dijadikan variabel yang mempengaruhi locus of control. Lebih lanjut, pengaruh kausal empiris antara variabel good governance dan komitmen profesional ini dapat digambarkan melalui persamaan $1 . \mathrm{Y}_{1}=\beta_{1.1} \mathrm{X}_{1}+$ $\beta_{1.2} X_{2}+\epsilon_{1}$, atau $Y_{1}=0,544 X_{1}+0,216 X_{2}+0,765$ $\epsilon_{1}$.

2. Persamaan 2: $Y_{2}=\beta_{2.1} X_{1}+\beta_{2.2} X_{2}+\beta_{2.3} X_{3}$ $+\mathrm{C}_{2}$

Secara simultan pengaruh good governance, komitmen profesional dan locus of control terhadap akuntabilitas adalah sebesar 0,923 atau $92,30 \%$, sisanya $6,70 \%$ dipengaruh faktor lain di luar model. Model simultan terjadi signifikan, dengan memperhatikan probablitas $\mathrm{F}$ sebesar 259,862 pada sig $0,000<0,05$. Setelah model simultan terbukti signifikan, maka dilakukan penelusuran jalur pengaruh parsial. Dari tiga variabel yang ditempatkan sebagai prediktor, good governance memiliki t-hit $>$ t-tab dan pvalue $>0,05$, sehingga dapat dikatakan bahwa good governance secara parsial berpengaruh tetapi tidak signifikan terhadap akuntabilitas. Besaran pengaruh langsung good governance terhadap akuntabilitas adalah sebesar $-0,076$ atau dibulatkan menjadi $-7,60 \%$. Artinya, tinggi rendahnya akuntabilitas mampu dipengaruhi oleh good governance sebesar $-7,60 \%$ sedangkan sisanya dipengaruhi faktor lain di luar model Komitmen profesional memiliki t-hit $<\mathrm{t}$-tab dan pvalue $>0,05$, sehingga dapat dikatakan bahwa komitmen profesional secara parsial tidak berpengaruh signifikan terhadap akuntabilitas. Besaran pengaruh langsung komitmen profesional terhadap akuntabilitas. adalah sebesar 0,046 atau dibulatkan menjadi $4,60 \%$. Artinya, tinggi rendahnya akuntabilitas. hanya mampu dipengaruhi oleh komitmen profesional sebesar $4,60 \%$, sedangkan sisanya $65,40 \%$ dijelaskan faktor lain di luar model.

Locus of control memiliki t-hit $>$ t-tab dan pvalue $<0,05$, sehingga dapat dikatakan bahwa locus of control secara parsial berpengaruh signifikan terhadap akuntabilitas. Besaran pengaruh locus of control terhadap terhadap locus of control adalah sebesar 0,989 atau $98,90 \%$. Artinya, tinggi rendahnya akuntabilitas dipengaruhi oleh locus of control sebesar 98,90\%, sedangkan sisanya $1,10 \%$ dipengaruhi faktor lain di luar model. Dari tiga variabel yang digunakan sebagai prediktor akuntabilitas, variabel locus of control teridentifikasi sebagai variabel terkuat yang mempengaruhi akuntabilitas dibanding dua variabel lain yaitu good governance dan komitmen profesional. Hal ini tentunya menjelaskan bahwa secara simultan dan parsial good governance, komitmen profesional dan locus of control dapat dijadikan variabel yang mempengaruhi akuntabilitas. Lebih lanjut, pengaruh kausal empiris antara variabel good governance, komitmen profesional dan locus of control ini dapat digambarkan melalui persamaan 2. $Y_{2}=\beta_{2.1} X_{1}+\beta_{2.2} X_{2}+\beta_{2.3} X_{3}+\epsilon_{2,}$ atau $Y_{2}=$ $-0,076 X_{1}+0,046 X_{2}+0,989 X_{3}+0,272 e_{2}$. Secara keseluruhan, pengaruh-pengaruh yang dibentuk dari ke-2 persamaan dapat digambarkan yaitu $\mathrm{Y}_{1}=\beta_{1.1} \mathrm{X}_{1}+\beta_{1.2} \mathrm{X}_{2}+\epsilon_{1}$, atau $\mathrm{Y}_{1}=0,544 \mathrm{X}_{1}$ $+0,216 X_{2}+0,765 \epsilon_{1}$ dan $Y_{2}=\beta_{2.1} X_{1}+\beta_{2.2} X_{2}$ $+\beta_{2.3} X_{3}+\epsilon_{2,}$ atau $Y_{2}=-0,076 X_{1}+0,046 X_{2}+$ $0,989 \mathrm{X}_{3}+0,272 \mathrm{e}_{2}$. Berdasarkan hasil pengujian tersebut di atas diperoleh diagram jalur empiris untuk model Y sebagaimana yang dijelaskan gambar berikut ini: 


\section{Gambar 3.}

Diagram Jalur Empiris (Standardized, $\mathbf{N}=66$ )

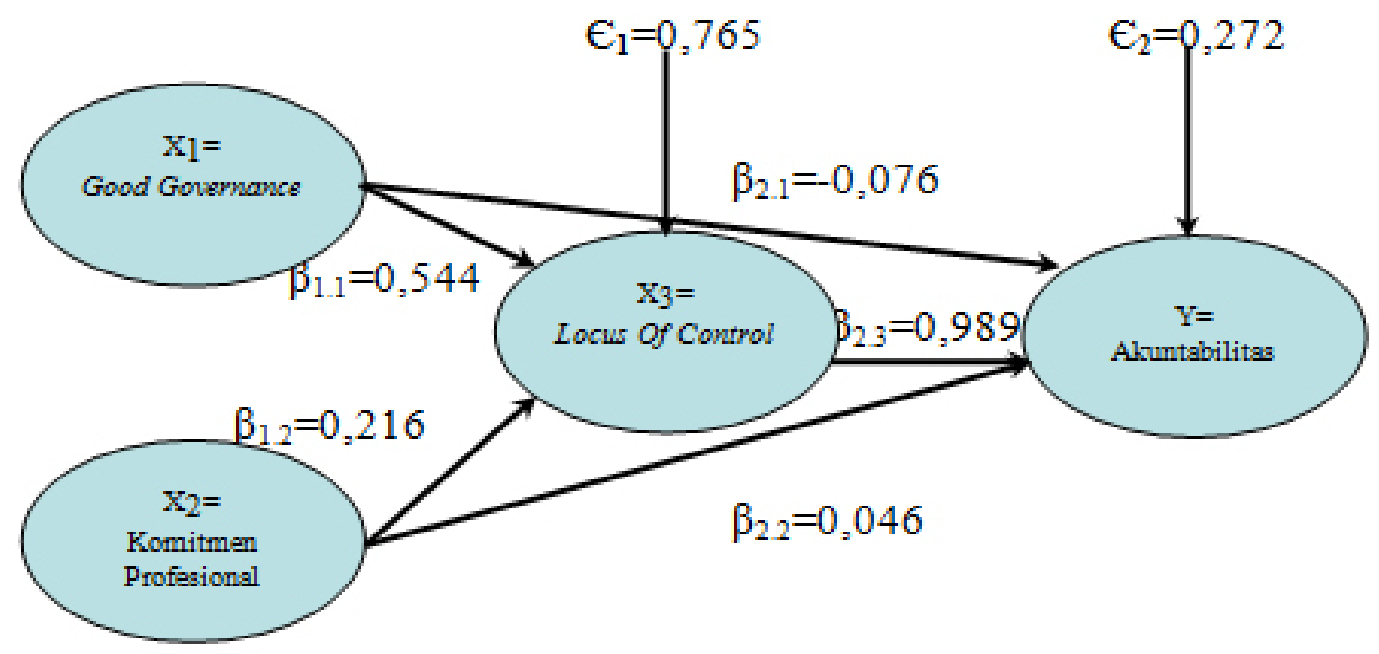

Tabel 3.

Ringkasan Hasil Estimasi Parameter Model

\begin{tabular}{ccccc}
\hline Model & Koefisien Jalur & T & Sig & R2 \\
\hline $\begin{array}{c}\text { Persamaan 1: } \\
Y_{1}=\beta_{1.1} X_{1}+\beta_{1.2} X_{2}+\epsilon_{1} \\
\left(\boldsymbol{\beta}_{1.1}\right)\end{array}$ & & & & \\
$\left(\boldsymbol{\beta}_{1.2}\right)$ & 0,544 & 5,383 & 0,000 & 0,415 \\
Persamaan 2: & 0,216 & 2,139 & 0,036 & \\
$Y_{2}=\beta_{2.1} X_{1}+\beta_{2.2} X_{2}+\beta_{2.3} X_{3}+C_{2}$ & & & & \\
$\left(\boldsymbol{\beta}_{2.1}\right)$ & $-0,076$ & $-1,728$ & 0,890 & \\
$\left(\boldsymbol{\beta}_{2.2}\right)$ & 0,046 & 1,222 & 0,227 & 0,925 \\
\hline
\end{tabular}

Pengaruh tidak langsung/indirect effect (IE), good governance ke akuntabilitas melalui locus of control, sebagaimana terlihat pada Persamaan 1, adalah IE $=\beta_{1.1} X_{1} \times \beta_{2.3} X_{3}=(0,544)$ $\mathrm{x}(0,989)=0,538$. Dengan demikian pengaruh totalnya $=\beta_{2.1} X_{1}+I E=-0,076+0,538=0,462$. Sehingga dapat dikatakan bahwa locus of control memediasi hubungan antara good governance dengan akuntabilitas. Besaran pengaruh locus of control dalam memediasi adalah sebesar 0,462 atau $46,20 \%$. Artinya, tinggi rendahnya pengaruh locus of control dalam memediasi hubungan antara good governance dengan akuntabilitas sebesar $46,20 \%$, sedangkan sisanya $53,80 \%$ di- pengaruhi faktor lain di luar model. Pengaruh tidak langsung/indirect effect (IE), komitmen profesional ke akuntabilitas melalui locus of control, sebagaimana terlihat pada Persamaan 2 adalah $\mathrm{IE}=\beta_{1.2} \mathrm{X}_{2} \times \beta_{2.3} \mathrm{X}_{3}=(0,216) \times(0,989)$ $=0,214$. Dengan demikian pengaruh totalnya $=$ $\beta_{2.2} X_{2}+I E=0,046+0,214=0,260$. Sehingga dapat dikatakan bahwa locus of control memediasi hubungan antara komitmen profesional dengan akuntabilitas. Besaran pengaruh komitmen profesional dalam memediasi adalah sebesar 0,260 atau $26,00 \%$. Artinya, tinggi rendahnya pengaruh locus of control dalam memediasi hubungan antara komitmen profesional dengan 
akuntabilitas sebesar $26,00 \%$, sedangkan sisanya $74,00 \%$ dipengaruhi faktor lain di luar model.

\section{Simpulan, Keterbatasan dan Implikasi Hasil Penelitian}

Penelitian ini bertujuan untuk mengetahui pengaruh good governance dan komitmen profesional terhadap akuntabilitas aparat layanan pengadaan barang/jasa pemerintah dengan locus of control sebagai intervening. Berdasarkan hasil penelitian maka dapat diambil kesimpulan sebagai berikut :

1. Good governance secara parsial tidak berpengaruh signifikanterhadapakuntabilitas, sehingga bila good governance tinggi tidak menjamin apakah yang bersangkutan akan melakukan pekerjaan dengan akuntabilitas tinggi. Hal ini disebabkan karena good governance dalam hubungannya dengan akuntabilitas sangat memerlukan faktor lain salah satunya faktor locus of control. Hasil penelitian ini sejalan dengan penelitian Kodar Udoyono (2012) di Kota Yogyakarta yang menyatakan bahwa e-Procurement (good governance) dalam Pengadan barang/ jasa pemerintah fisibel tapi tidak akuntabel.

2. Komitmen profesional tidak berpengaruh signifikan terhadap akuntabilitas, sehingga bila komitmen profesional tinggi tidak menjamin apakah yang bersangkutan akan melakukan pekerjaan dengan akuntabilitas tinggi. Hal ini disebabkan karena komitmen profesional dalam hubungannya dengan akuntabilitas sangat memerlukan faktor lain salah satunya faktor locus of control.

3. Locus of control berpengaruh secara signifikan terhadap akuntabilitas aparat layanan pengadaan barang/jasa pemerintah. Hal ini disebabkan karena untuk meningkatkan akuntabilitas seorang aparat layanan pengadaan barang/jasa pemerintah sangat bergantung pada tingkat loncus of control nya. Jika seorang aparat layanan pengadaan barang/jasa pemerintah memiliki loncus of control yang tinggi maka akan dengan mudah melakukan tugas-tugasnya dan sebaliknya jika rendah maka dalam melaksanakan tugasnya akan mendapatkan kesulitan-kesulitan sehingga akuntabilitas hasil pekerjaan akan rendah pula.

4. Good governance dalam hubungannya dengan akuntabilitas ternyata sangat memerlukan faktor lain sebagai intervening yaitu faktor locus of control. Hal ini menunjukkan bahwa untuk meningkatkan akuntabilitas layanan publik tidak hanya bergantung pada tingkat good governancenya saja tetapi juga bergantung pada tingkat locus of controlnya. Jika seorang aparat layanan pengadaan barang/jasa pemerintah memiliki good governance yang tinggi tidak dapat dipastikan bahwa akuntabilitas hasil pekerjaannya akan tinggi pula karena untuk mencapai akuntabilitas yang tinggi ternyata harus memiliki locus of control yang tinggi pula.

5. Komitmen profesional dalam hubungannya dengan akuntabilitas ternyata sangat memerlukan faktor lain sebagai intervening yaitu faktor locus of control. Hal ini menunjukkan bahwa untuk meningkatkan akuntabilitas layanan publik tidak hanya bergantung pada tingkat komitmen profesionalnya saja tetapi juga bergantung pada tingkat locus of controlnya. Jika seorang aparat layanan pengadaan barang/jasa pemerintah memiliki komitmen profesional yang tinggi tidak dapat dipastikan bahwa akuntabilitas hasil pekerjaannya akan tinggi pula karena untuk mencapai akuntabilitas yang tinggi ternyata harus memiliki locus of control yang tinggi pula.

\section{Daftar Pustaka}

Adimaja, 2010. Pengaruh Penerapan pengadaan barang/jasa pemerintah secara on line terhadap Peningkatan Kualitas Kinerja dan Pelayanan Publik pada Dinas Pendidikan Propinsi Kepulauan Riau. Tesis Perpustakaan Universitas Terbuka.

Ita Akyuna Nightisabha, Djoko Suhardjanto dan Bayu Tri Cahya Agustus 2009 Persepsi 
Pengguna Layanan Pengadaan Barang dan Jasa pada Pemerintah Kota Yogyakarta terhadap Implementasi Sisteme-Procurement. Jurnal Siasat Bisnis Vol. 13 No. 2.

Instruksi Presiden nomor 1 tahun 2013 tentang Aksi Pencegahan dan Pemberantasan Korupsi tahun 2013.

Paul Phillips and Wojciech Piotrowicz. April 2006. e-procurement: How does it enhance strategic performance? Kent Business School, University of Kent, Canterbury, UK Working Paper No.113.

Udoyono, Kodar.2012. e-Procurement dalam Pengadaan Barang dan Jasa Untuk Mewujudkan Akuntabilitas di Kota Yogyakarta. Jurnal Studi Pemerintahan Volume 3 Nomor 1 Februari 2012.

United Nations. 2011. Supplement to the Annual Statistical Report on United Nations Procurement Transparency and public procurement.

Undang-Undang Dasar Negara Republik Indonesia Tahun 1945.

Undang-Undang Nomor 1 Tahun 2004 tentang Perbendaharaan Negara (Lembaran Negara Republik Indonesia Tahun 2004 Nomor 5, Tambahan Lembaran Negara Republik Indonesia Nomor 4355).

Undang-undang nomor 11 tahun 2008, tentang Informasi dan Transaksi elektronik. 